\title{
The Use of Knowledge Capital in a Region Through Building a Network of Cooperation Between the Public and Private Sector
}

\author{
Beata Wierzbicka, Jędrzej Strumiłł"
}

\begin{abstract}
In the times of information civilization knowledge is treated as a very important factor of every single organisation. That factor, due to the abilities and experience of the members of a community, allows using other resources in a more optimal way when it comes to prioritizing the development of an organisation. Nowadays, knowledge is a very valuable factor in cooperation among all the business entities of socioeconomic life.

Knowledge, and particularly the process of spreading knowledge among entities within a region, allows for the efficient and successful accomplishing a creative community's development strategies.

The aim of the article is to indicate the need for cooperation between the public and private sector in the effective management of community knowledge potential due to creating present and future prosperity.
\end{abstract}

Keywords: region, learning organisation, public sector, globalisation

\section{Introduction}

Poland's access to the European Union has undoubtedly created new opportunities for Polish regions as well as new challenges. This article analyses the regions ${ }^{1}$ as the organisation formed by the community and of its residents.

Competitiveness level and the development chances of Polish regions are determined to a large degree by the factors inherent in their environment. Taking into consideration the fact that the development of the region is performed by a region's community for exactly this community, we must consider the internal conditions as those which determine the process of choosing the way of development. The knowledge, the abilities, common values seen by a community, ability to cooperate and decision making - these are the factors that determine the development and direction. According to the simple correlation between economic success and the quality of life of a region's residents, in the process of a region's development we should implement the modern management concepts, which are verified in the organisations performing in a developed global economy. Nowadays, the most significant role in the

\footnotetext{
*dr Beata Wierzbicka, Uniwersytet Gdański, Wydział Zarządzania, e-mail:wierzbickabeata@o2.pl; dr Jędrzej Strumiłło, Uniwersytet Gdański, Wydział Zarządzania, e-mail: jstrumillo@wzr.ug.edu.pl.

${ }^{1}$ The analysis concerns the regions defined in the European Union as an administrative level below the national level. In Poland, these are self-governing provinces that, as a result of political reform, achieved their subjectivity.
} 
process of development is the flow of knowledge that creates relations among participants of socio-economic life. The local accumulation of knowledge is of strategic importance in promoting endogenous region development.

\section{Globalisation and the range and pace of changes in socio-economic space}

The period of civilization development that we live in, is undoubtedly completely different (to the past) in terms of the scale and the range of changes. There were truly epochal inventions in previous periods. Although these inventions have fundamentally shaken many social orders, they were located within the borders of one community so they were local in nature. The effects of current circumstances, due to technological progress, spreads rapidly throughout the world causing repercussions in the fields of economy across the whole world and stimulating the changes in the lives of societies in many parts of our planet. There has been a significant increase in the range and scale of changes but most of all the pace of those changes has changed. Speaking about the pace of changes, we should consider the number of events that significantly influenced the standard of living of modern civilization. This process made a strong impact in the area of technical innovation that have considerably changed the image of the world's economy. Every day scientists make new discoveries and what is more, these discoveries are much more quickly applicable in practice. The driving force of all the changes taking place is knowledge (Moss, Kantor 1973, pp. 19-21). This knowledge allows determining how to use available means best as to make them successful. Treating knowledge as an important resource changes the structure of society fundamentally. That also creates new social and economic forces as well as new politics, which P.F. Drucker describes as the 'management revolution' (Drucker 1999, p. 42).

Globalisation has caused a decrease in the sense of isolation existing in many developing countries and has provided residents with unreachable before access to knowledge. Globalisation is also stimulated by international corporations, which relocate not only capital and goods but also technology. It could be disadvantageous for new foreign companies entering the market, which were protected in Poland before, as they were state-owned companies. Nevertheless, those companies contribute to introducing new technologies, gaining access to new markets and creating new branches of the economy. The world is becoming more and more connected and it does not matter if we consider a company or a country, their threats and opportunities depend on those, who create connections with them. Globalisation, as Thomas L. Friedman claims, can be characterised by one word: the 'network' (Friedman 2001, pp. 25, 27).

That network structure creates the image of current society, which is becoming increasingly a network society (Castells 1996, pp. 378-414). The network structures, according to J.G. Lambooy, are far more effective than other structures, especially in cases of uneasy markets and sudden changes in technology. The networks are particularly advantageous in situations requiring a quick and exact flow of information, which are key to social and 
trade reasons (Lambooy 1995, pp. 15-23). The idea of the network is strictly connected to the innovation issue because of the fact that both of them become the basic tool of competition in open markets. The network structures are the most effective ones, not only as far as the diffusion of innovations is concerned but also for stimulating and immediate transfer in applying innovations to the production process. The diffusion of knowledge connected to innovations and creating new innovations becomes the indicator of development.

Globalisation is the process which forces the market's, the technology's and the countries' integration. That is the reason for accessing the world faster, cheaper, at a greater and deeper range by people, communities and countries. And vice versa. The world can access some people, communities and countries at a deeper and greater range, cheaper and faster (Stiglitz 2007).

\section{Cooperation between the public and private sector in using the knowledge in the process of management}

To achieve success organisations have to adapt to new challenges that determine development direction. The most common way, that is used, is implementing creative ways of solving problems and searching for the best methods of facing growing competition in the global economy. Organisations have to be aware of the increasing requirements from better and better educated and independent units that make their choices in professional, consumer and social activities on their own. From political and economic organisations the community as the whole expect full transparency in rules and functioning mechanisms, reliability, effectiveness and responsibility in the used norms and procedures (in all actions taken).

In the process of strategic management, the ways in which an organisation acquires resources and manages them to obtain the key competences (that differentiate the organisation from others present on the market) are the most relevant.

In the post industrial age, in the time of widespread access to traditional generation sources, the effectiveness of companies, regions or countries determines those resources which can guarantee stability in creating an innovative economy. The idea of knowledge provides competitiveness in a more and more dynamically developing as well as unpredictable environment, becomes an integral part of the management concept of modern organisations.

The creation and efficient use of intellectual potential of a region is the result of learning thorough an organisation. The potential of individuals (the members of a region's community) is created in the process of individual knowledge obtained through education and enriched by experience gained in family and school life or workplace events. The knowledge of particular members of an organisation to become an intellectual capital of an organisation, which can be used in strategic decision making, must be managed. The region, as the learning organisation, to manage the intellectual capital must develop ways of transferring individual knowledge and experience of residents into the knowledge of the whole 
community, the so called region's intellectual capital (Rokita 2003, p. 10). In the process of strategic planning, implementing strategies and their verification, the knowledge of individual residents and the entire community should be identical. They should penetrate each other; include all institutions of the world of politics, science, economy, non-profit sectors and also their areas of activity.

The competiveness of the quality of intellectual capital possessed by a region and the effectiveness of using it in strategic activities determines its position in modern economy. Meeting its challenges consists not only in companies' openness for new products and process innovations but first of all in active participation of partners in creating and the diffusion of knowledge. The most important areas for future success are: creative thinking, thought leadership, active cooperation with the simultaneous competition of entities creating the total socio-economic value of the region. The multidirectional exchange of information, knowledge and experience favours creating a network of direct relations among individual partners in a region.

The basis for forming a circle of knowledge and innovation is the strong position of companies in a region. This circle consists of very widely branched, differential network of connections of a local and non-local nature, even global in some areas.

The networks connect suppliers and recipients, big and also small companies. These relations are characterised by widely understood cooperation, also among competitors, which the Silicon Valley is an example. The concentration of companies, from the same or connected closely with each other branches, in relatively small or limited (but not so strictly) space, implies numerous advantages for those companies as well for the whole region (Sternberg 1966, pp. 518-538). A region's economy, based on close companies' cooperation is a source of dynamic development, offers relatively well paid workplaces, and favours the participation of different environments in the regional economic policy of public authorities. Such an institutional connection allows creating great opportunities for information and ideas exchange and then forms reliance and economic cooperation. In the process of building partnerships among social and economic units, the most important becomes the individuals' and organisations' knowledge.

In the information age knowledge is treated as a very significant factor of a company's resources or even as a main resource, which due to the abilities and experience of the members of an organisation allows to use other resources in a more optimal way, from the point of view of an organisation's priorities. Considering the fact, that knowledge is the resource integrating other resources in an organisation, the activities of an organisation based on this knowledge allow better possessed potential management and adapt to the direction of

\footnotetext{
${ }^{2}$ In Silicon Valley, one of the most dynamically developing regions in the world, there is a minimal involvement of citizens in actions in favour of public affairs. At the same time there is a highly developed form of capital, in the form of a dense network of cooperating economic institutions, companies and organizations supporting economic development. Social capital is present as a network of informal contacts based on the exchange of knowledge, information and experience of economic importance (Cohen, Fields 2000, pp. 16-285).
} 
undertaken actions to changing environmental conditions. The knowledge also manages the organisation in a more optimal way through integrating all of its members around a common development vision. 'The appropriate use of this resource - as B. Nogalski emphasises - has a fundamental influence on the organisation's success' (Kowalczyk, Nogalski 2007, p. 32). The process of learning should guarantee a regional community to make a decision that enables ad hoc and perspective actions and also desired skills and values to be complete and together. However, the implementation of an organised learning process requires fulfilling exact conditions (Garrat 2001, pp. 3-8). Firstly, there must be a belief about a key and lasting value of investment in human capital and the learning process in an organisation. Both those values are increasingly regarded as the ones strictly connected to a conscious organisation's effectiveness increase. Second, it is necessary to build an organisation's culture, which would guarantee the appropriate process of learning in three dimensions:

- learning, taking place at the level of cooperation of an organisation with the environment, focusing on outside effectiveness through achieving the main targets,

- strategic learning, focused on the level of a view and strategy of a region, integrating all of the members of the organisation around the problems and strategic decision making,

- operational learning, focused on activities resulting from the programs, which result in achieving a high level of satisfaction by internal and external customers.

The levels that create a learning region's construction interfere with each other in a complex and often unpredictable way. To improve the management process, there is not only a flow of information between them but also a diffusion of knowledge.

The diversity of entities in a region can contribute to the better exchange and spread of knowledge and a better adaptation of the activities to real requirements.

Cooperation builds human relationships based on trust and common perceived values implementing the formation of relationships that create active and creative social attitudes, which culturally enrich an entire community of residents.

A particularly important role in the construction of a 'learning region' play a region's political authorities, that are responsible for leadership. Leadership defined by R. Rutka: '(...) is based primarily on the induction of the members of the team such emotional states that will motivate them to involved cooperation in creating and implementing a common mission, purposes and activities (Rutka 2001, p. 114). On the politicians, who assume responsibilities of leadership, lies strong responsibility. Their knowledge, skills and experience affect the entire process of managing the development of a local government community. According to the concept of a learning region (by B. Garratt), authorities play the role of the brain in an organisation. The brain which is responsible for the process of knowledge creation, using and expanding it among the members of an organization (Garratt 2001, p. 82).

Leadership in a learning region is responsible for creating a climate for cooperation and interaction between all the entities of socio-economic life. The synergy effect, which creates greater economic and social benefit (than it would emerge as the result of the activities of 
various individual entities), becomes real with effective leadership in the region. Cooperation based on the principles of partnership allows partners to use knowledge resources better and to reduce operating costs. Avoiding the duplication of individual actions enables the effective and efficient implementation of the strategic assumptions of a regional community.

\section{Premises and barriers facilitating the implementation of the concept of a learning region}

Developed by the Ministry of Regional Development in 2010, 'the National Regional Development Strategy 2010-2020: Regions. Cities. Rural areas' (Polish Monitor, 2011), the perception of the regional policy, as the main instrument of achieving the national development objectives in a territorial structure, entails the necessity of multi-level governance in various sector policies. This means that the implementation of development goals corresponds to different public and non-public entities located in regions, therefore, for the effective and efficient implementation of regional policy it is crucial to ensure the effective coordination of activities undertaken by various entities, both in a vertical and in horizontal system. This cooperation is important at all stages of the implementation of a strategy, at the stages of its construction and implementation as well.

In the long run the policy of regional institutions should contribute to implementing such methods of management in the socio-economic space of a region that increase its innovativeness and competitiveness on a global scale. In a region, in order to coordinate all activities in the area of management, a permanent team should be established. However, to achieve success, its composition should consist of professionals from both regional and local authorities, as well as from local business. The tasks of the team are very important at the stage of developing a vision, being based on a realistic assessment of the strengths of a region which are unique and commercial enough to create a basis for increased added value and to develop a long-term activity plan for the achievement of goals as its basis (Wierzbicka 2014, pp. 180, 190).

In recent years, in the global economy there have emerged trends that have significantly changed the conditions of the functioning of companies as well as countries and regions. The most significant ones are technical and technological progress; increase of the role of knowledge as a strategic resource and (resulting from an open global economy) the entrance of international companies on local markets. Those trends have contributed to the diversification of companies under the influence of the environment. The companies that do not recognize the changes or did not want to see them (because of the fear of the unknown), as well as those, which base their activities on imitation only, they struggle to survive on the market (with a negative result often), or barely economically exist in the best case. The ones that actively use the opportunities emerging in the environment and by implementing the innovations create a new reality and achieve a more and more growing position on the market. 
In a knowledge based economy, the implementation of innovations, as a source of diversification of the economy, becomes a reality due to the significant accumulation and diffusion of knowledge between private sector companies as well as between private and public sector companies. The diffusion of knowledge is done through a variety of publications, reports, scientific lectures and discussions at seminars or conferences. However, for the flow of knowledge between the private and public sectors this is not a satisfying enough system. Public sector institutions should contribute to creating a climate favouring the innovation of market entities in the space in which these processes take place. Connecting the strategies of both sectors is a challenge for the modern economy, at both national and regional levels. The necessity of supporting the development of an innovative economy in Poland was highlighted in many documents, both at national and regional levels. Support for such projects can be obtained from regional and national programmes implemented at the EU-level. Comprehensive awareness of the current and planned support instruments provides The Enterprise Development Programme until 2020, which was approved by the Council of Ministers on April 8, 2014. This program is a proposal for a system of support of enterprises in Poland, with a particular focus on their innovativeness. It also includes the aspect of removing barriers and creating a favourable business environment, as well as active actions to increase their innovativeness and competitiveness (Entrepreneurship in Poland, 2014, 23.03.2016). The considered and described actions are to contribute to the development of the National Innovation System, understood as a network of cooperating, in public and private sector, institutions. The activity and interactions between them should initiate the use of individual and organisational knowledge for the development of innovation.

The demonstration of premises and barriers that enables the implementation of the concept of a learning region, in the Polish socio-economic reality, was an inspiration for the research conducted from the year 2010-2014. The study was of an open character. It was focused on recognising the social phenomena and interpretation of the cause and effect relationships between them. The main techniques of collecting empirical material were the interviews with managers of private and public organizations ${ }^{3}$. During the interviews, the managers were asked for example about the importance of factors enabling the implementation of the learning region concept, as a way of creating a climate of innovation-oriented economic and social space. They were also asked to identify the threats to the implementation of this concept. Chosen conclusions from those interviews are presented in Figure 1.

\footnotetext{
${ }^{3}$ The research was conducted on a group of 62 managers of small and medium-sized companies, 2 managers of large companies and several representatives of public institutions. Due to the fact that permission to interview were obtained thanks to the personal contacts of interviewers and on their own, it was not possible to carry out the research on a representative group (in the full sense of the word). Conducting such a project on a wider scale could be definitely an interesting research challenge.
} 


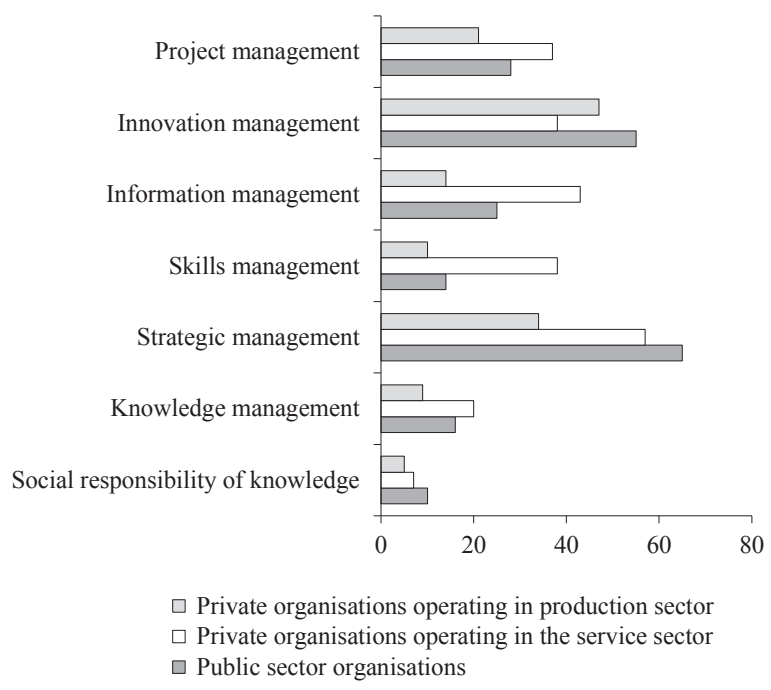

Figure 1. The use of knowledge capital in the region by building a network of cooperation between the public and private sectors

Source: own study based on analysis of interviews.

The results of the research confirm the previous knowledge about the ways managers $^{4}$ make decisions about development processes. During decision making managers rely mainly on their own experience and use their personal networks. However, this knowledge seems insufficient to make profound changes to form strategic innovations. Both the micro and small companies (as the major components of Polish business structure) rarely diversify their activities due to concerns connected with entering new unknown areas of the market. A common feature of these companies is the limited possibility of the observation of the environment. This is due to the fact that often they cannot afford to buy expensive studies or market forecasts or even employ a specialist in this field. However, entrepreneurs show great determination in their actions. This motivation is especially valuable because of the numerous threats they face in building cooperation in the region (Figure 2).

On the basis of the interviews, there were also other properties specified such as flexibility in the way decisions are made, openness to changes in the environment and in individual cases with a high level of knowledge resulting in creative thinking. However, processing this creativity into innovation encounters (in the economic reality) serious obstacles related to the access to financing the innovation processes. Business integration, which could

${ }^{4}$ Research on knowledge management processes in micro-enterprises were presented, among others, by S. Gudkova (2008) 'Development of small businesses. Knowledge, networks of personal connections. The process of learning', Warsaw and D. Janczewska (2012), 'Logistic activities supporting knowledge transfer from R \& D to SMEs sector', (Entrepreneurship and Management, SAN in Lodz, Logistics Management, Volume XIII, Published Book 16). 
significantly accelerate the diffusion of knowledge, so important in the processes of innovation management, according to the statements of entrepreneurs, is unrealistic because of the lack of effective forms of communication within society and the low level of social trust.

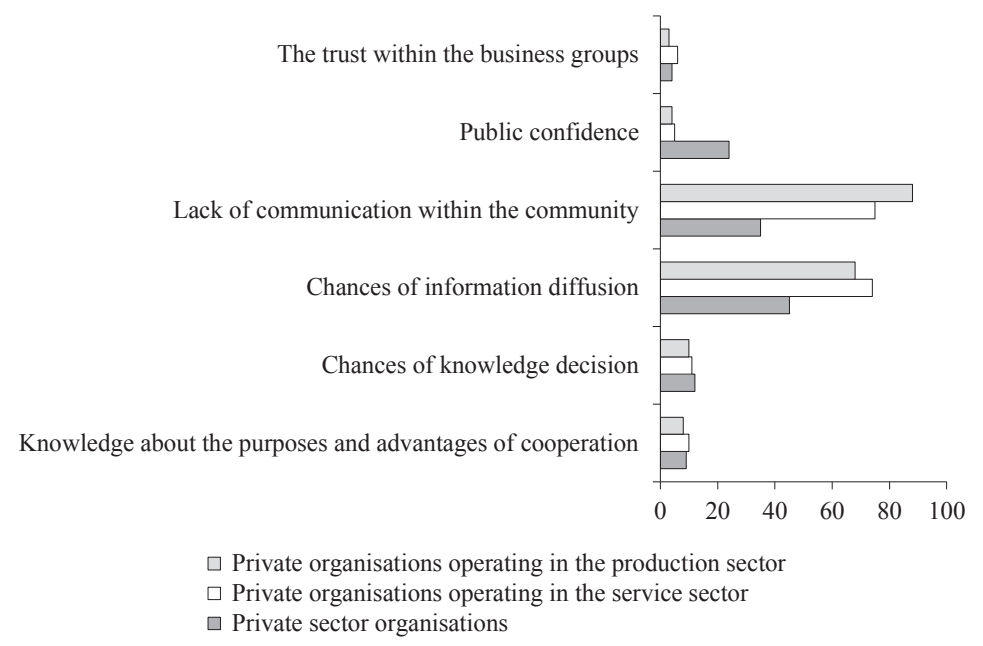

Figure 2. Threats in the process of building cooperation of organizations in the region (\% of responses)

Source: own study based on the analysis of interviews.

K. Zimniewicz highlights the dilemma faced by every manager. In the case of a region this concerns a representative body. This dilemma is the gap between short-term effectiveness and long-term changes. He admits that at the centre of decision-makers should not be short-term successes but rather long-term oriented activities. The latter can be achieved, according to the author, only by support from the learning process that allows finding the answers to key questions. The key questions are: 'What main benefits does a region want to possess in the future? Should there be the changes in innovation, culture or other values?' (Zimniewicz 1999, pp. 88-90).

\section{Concluding remarks}

Structural changes in OECD countries have resulted in an increase in the importance of knowledge and information as intangible capital in the management process of companies and the national economy as well. Knowledge is important not only for the sectors based on modern technologies, where definitely it is a dominant resource, but also for the traditional sectors of the economy, for which it is a source of inspiration creating the process of change. Innovation does not currently depend on the individual activities of companies 
only or universities and research institutes but mainly on the cooperation between them. Authority institutions, academic environments and the economy sector must create a common system for the transfer of technology, information and knowledge between economic, social and political entities.

In modern international systems the ability to compete depends mainly on the possibilities of using the knowledge and skills of the employees as well as the ability to establish cooperation between different entities for the economic growth and social welfare.

Being aware of the fact that we live in a time of qualitative changes a society wishing to succeed must transform. The role of leaders is to manage these changes in such a way that they would be fully accepted by a society where the members understand the changes and are ready to accept them as well as to prepare for the changes and transform them for their own benefit. In such a situation only society will become the main beneficiary of the changes taking place in the modern world.

\section{References}

Castells M. (1996). The Rise of the network Society, Cambridge.

Cohen S.S., Fields G. (2000). Social capital and capital gains: An examination of social capital in Silicon Valley. In: M. Kenney (ed.), Understanding Silicon Valley: The anatomy of an entrepreneurial region. Stanford

Drucker P.F. (1999). Spoleczeństwo pokapitalistyczne. Warszawa: Wydawnictwo Naukowe PWN,

Friedman T.L. (2001). Lexus i drzewo oliwne. Zrozumieć globalizację. Poznań: Dom Wydawniczy Rebis.

Garratt B. (2001). The Learning organization. Developing Democracy at work. London.

Kowalczyk A., Nogalski B. (2007). Zarządzanie wiedza. Koncepcje i narzędzia. Warszawa: Difin.

Lamboy J.G. (1995). Structural change: Economic and geographical perspectives. In: A. Kukliński (ed.), Baltic Europe in the Perspective of global change, Europe 2010 series1. Warszawa.

Lechicka-Kostuch M. (2008). Determinanty rozwoju polskich regionów. Sopot: Fundacja Rozwoju UG.

Monitor Polski, Dz.U. RP, w36, poz.423, Warszawa 20 maja 2011.

Moss Kantor R. (1973). Innovation for Productivity in the American Corporation. Chicago.

Porter M.E. (1992). Competitive adventage of nations. London.

Przedsiębiorczość w Polsce 2014 (2014). Sieć Regionalnych Strategii Innowacji, http://www.mr.gov.pl (23.03.2016).

Rokita J. (2003). Organizacja uczaca się, Akademia Ekonomiczna w Katowicach. Katowice.

Rutka R. (2001). Kierowanie. In: A. Czermiński et al. (eds.). Zarządzanie organizacjami. Toruń: Dom Organizatora.

Sternberg R. (1996). Regional growth theories and high-tech regions. International Journal of Urban and Regional Research, 3 (20).

Stiglitz J.E. (2007). Wizja sprawiedliwej globalizacji Propozycje usprawnień. Warszawa: Wydawnictwo Naukowe PWN.

Wierzbicka B. (2014). SKW jako element zarządzania strategicznego w budowaniu współpracy w regionie w obliczu zagospodarowania środków unijnych w nowej perspektywie pomocowej. Zeszyty Naukowe Uniwersytetu Szczecińskiego $\mathrm{nr} 802$.

Zimniewicz K. (1999). Wspótczesne koncepcje i metody zarządzania. Warszawa: Wydawnictwo Naukowe PWN. 


\section{WYKORZYSTANIE KAPITALU WIEDZY W REGIONIE POPRZEZ BUDOWANIE SIECI WSPÓŁPRACY MIĘDZY SEKTOREM PUBLICZNYM I PRYWATNYM}

Streszczenie: Wiedza traktowana jest $\mathrm{w}$ dobie cywilizacji informacyjnej jako bardzo ważny czynnik zasobowy każdej organizacji, który dzięki umiejętnościom i doświadczeniu członków jej społeczności pozwala na wykorzystanie pozostałych zasobów w sposób bardziej optymalny z punktu widzenia priorytetów rozwoju organizacji. Wiedza obecnie najlepiej sprawdza się we wspólnym działaniu wszystkich podmiotów życia społeczno-gospodarczego.

Wiedza, a szczególnie proces jej rozprzestrzeniania się pomiędzy podmiotami w regionie, pozwalają skutecznie realizować twórcze strategie rozwoju wspólnoty.

Celem artykułu jest wskazanie na potrzebę współpracy sektorów publicznego i prywatnego w skutecznym zagospodarowaniu potencjału wiedzy społeczności regionu w celu tworzenia jej obecnego i przyszłego dobrobytu.

Słowa kluczowe: wiedza, sektor prywatny, sektor publiczny, globalizacja

\section{Cytowanie}

Wierzbicka B., Strumiłło J. (2016). The Use of Knowledge Capital in a Region Through Building a Network of Cooperation Between the Public and Private Sector. Finanse, Rynki Finansowe, Ubezpieczenia, 4 (82/1), 851-861. DOI: 10.18276/frfu.2016.4.82/1-71. 